\title{
Slavný Prodromus motýlů Čech v souvislostech
}

\author{
Jan Šumpich \\ Národní muzeum - Př́rodovědecké muzeum, Entomologické oddělení, Cirkusová 1740, \\ 19300 Praha 9 - Horní Počernice; jansumpich@seznam.cz
}

Šumpich J. 2021: Slavný Prodromus motýlů Čech v souvislostech. - Journal of the National Museum (Prague), Natural History Series 190: 93-100.

V roce 1929 vydal Jacob Sterneck (1868-1941; celým jménem Jakob Maria Alfred Daublebsky von Sterneck zu Ehrenstein) vlastním nákladem na svou dobu velkolepé dílo Prodromus der Schmetterlingsfauna Böhmens [Prodromus motýlí fauny Čech] (dále jen Prodromus) (Sterneck 1929), které až do současnosti představuje základ české faunistiky tzv. velkých motýlů. Jeho vydání však předcházelo mnoho útrap a komplikací, které běžný uživatel-entomolog této knihy snadno přehlédne, pokud si nepřečte její úvod a další písemnosti s tím související. Nejen na tehdejší dobu, ale i v měřítku dnešních poměrů, se jedná o precizní dílo obsahující přehled všech motýlích druhů zaznamenaných do té doby v Čechách a ke všem význačnějším druhům i výčet všech lokalit s odkazy na zdroj. Precizně sestavený soupis encyklopedického charakteru založený na vysoké odborné erudici autora se stal výchozím zdrojem prakticky všech následujících prací o české fauně „velkých“ motýlů. V obsáhlém úvodu knihy autor popisuje stav dosavadní faunistiky motýlů v Čechách, kdy převažovaly pouze holé seznamy druhů bez uvedení konkrétních nálezů a také mimo jiné zmiňuje úzký vztah s Ottokarem Nickerlem (1838-1920), autorem do té doby nejvýznamnějších děl o motýlí fauně Čech. Právě O. Nickerl vyzval J. Sternecka k dokončení svého zamýšleného díla, nebot' sám již byl vážně nemocen a věděl, že svůj záměr nezvládne dokončit; z tzv. velkých motýlů zveřejnil pouze práci věnovanou píd’alkám (Nickerl 1907). J. Sterneck se této výzvy rád ujal a s pílí a pečlivostí jemu vlastní začal kromě vlastní sběratelské činnosti intenzivně komunikovat se všemi českými i německými sběrateli, kteří sbírali motýly na území Čech, zakládat faunistické karty k jednotlivým druhům a připravovat se na sepsání souhrnného díla. Zajímavá informace se nachází přibližně uprostřed úvodu, a totiž že dílo bylo nachystáno k tisku už v roce 1919 (!), ale „pro těžkou ekonomickou situaci“ nevyšlo. Zároveň uvádí, že tato první verze byla zpracována v mnohem širším měřítku - obsahovala poměrně obsáhlé kapitoly věnované klasifikaci motýlí fauny podle různých úhlů pohledu a také faunistické údaje ke všem zaznamenaným druhům. Vzhledem k tomu, že J. Sterneck byl okolnostmi donucen vydat Prodromus vlastním nákladem (všichni vydavatelé, které oslovil jej odmítli vydat), snažil se jej, pokud možno, co nejvíce zeštíhlit a tím snížit cenu za tisk ${ }^{1}$. Zvolil tedy stručnější formu prezentace dat, a kromě zmíněných kapitol vypustil i seznam druhů a akceptovaných aberací, který předcházel

1 Prodromus vyšel německy vlastním nákladem Sternecka s podporou pražského Ministerstva školství a národní osvěty, což bylo zřejmě důvodem, proč postoupil práva na pořízení českého překladu Československé společnosti entomologické. Ta tohoto práva nikdy nevyužila. 


\section{Box 1: Jakob Sterneck (*1868, Praha; +1941, Karlovy Vary)}

Vystudovaný právník, avšak zaměřením prírodovědec. Zpočátku se věnoval botanice, později zvítězili motýli. Od počátku 20. století do přibližně poloviny 30. let se intenzivně věnoval faunistice, později až do své smrti presedlal na taxonomii pídalek (Geometridae), které se věnoval na palearktické úrovni (položil základ systematiky podčeledě Sterrhinae). Sám motýly velmi intenzivně sbíral, a to vždy především $v$ místech svého profesního pưsobení (Cheb, Děčín, Praha, Trutnov), nejintenzivněji však $v$ Karlových Varech, kde byl po první světové válce jmenován okresním hejtmanem a zůstal zde až do své smrti. Byl mimořádně pečlivý a systematicky pracující, což jej predurčovalo stát se vůdčí osobností česko-německé lepidopterologické obce a díky intenzivním kontaktům s velký počtem německých i českých sběratelů byl, asi jako jeden z mála specialistũ tehdejší doby schopen se ujmout a zároveň dokončit práce na dvoudílném souborném díle o rozšíření motýlů v Čechách. Kromě Prodromu („velkých“) motýlů Čech z roku 1929, který dokončil sám, se významnou měrou zasloužil i o vydání druhého dílu věnovaného drobným motýlům, kde se spoluautorsky podílel Friedrich Zimmermann (1895-1961). Za svůj život napsal 14 botanických a 40 entomologických odborných prací. Zasloužil se o založení Sudetoněmeckého prírodovědného muzea v Libverdě u Děčína a byl zapojený do různých vědeckých spolků. Mimo jiné byl po mnoho let aktivním členem i Československé společnosti entomologické. Rozsáhlá sbírka motýlů byla po Sterneckově smrti darována jeho synem Př́rodovědeckému muzeu ve Vídni.

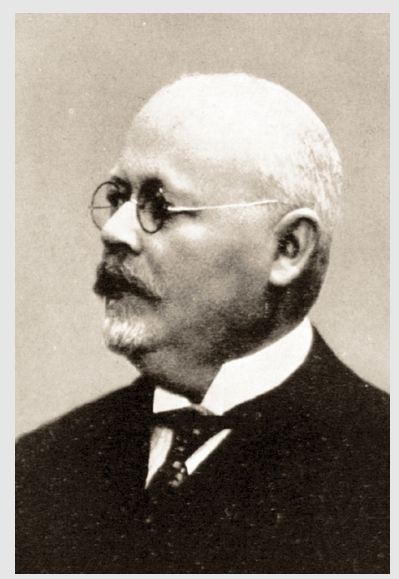

Obr. 1. Jacob von Sterneck. Fotograf neznámý, převzato z práce Laštůvka \& Liška (2011).

\section{Box 2: Adolf Binder (*12.9.1876, Vídeň; +19.2.1935, Wels)}

Syn vojenského účetního, $v$ Praze vystudoval lékařskou medicínu, svou profesní kariéru zahájil v jihočeských Nových Hradech a od roku 1909 působil jako lékař ve Stráži nad Ohří. Až do roku 1921, kdy se prestěhoval do Horních Rakous, entomologicky působil na rưzných místech Čech, především v Praze a okolí (1890 až 1903), v Českém krasu (údolí Berounky, Karlštejn, okolí Dobřichovic), okolí Teplic nad Metují, v Maštově u Podbořan (1892), u Doks (1896), Libouchec u Děčína (1895), $v$ údolí Labe u Litoměřic (1902 a 1908), v Mostě (1903 až 1907) a u Nových Hradů (1907-1908), pričemž nejintezivněji v Korunní u Stráže nad Ohří (1909-1920). Tuto etapu jeho života přerušila bohužel 1. světová válka, během které se účastnil bojů v Polsku, Korutanech a Jižním Tyrolsku, a za svou statečnost obdržel několik vyznamenání. Po prestěhování do Rakouska (Ampfelwang), kde pokračoval v lékařské praxi, začal velmi intenzivně sbírat v řadě oblastí, především v Alpách, podnikal však i expedice do Španělska, severní Itálie, Bulharska a Mad'arska. V Rakousku se obklopoval mimo jiné mladou generací entomologů, pro kterou byl vzorem a vedl ji $k$ vědeckému pohledu na tento obor. Pro svou nezištnost a otevřenost byl velmi oblíbený, ochotně pomáhal kolegům s determinací motýlů, a i díky jeho smyslu pro humor si uměl získat mnoho př́tel. Zatímco v Čechách byl entomologický odkaz A. Bindera téměr zapomenut, v Rakousku se dočkal všeobecné úcty (Anonymus 1935, Müller 1935). Za svůj život vybudoval obrovskou sbírku motýlů, kterou po predčasném úmrtí na rakovinu (ve věku 59 let) zakoupilo Hornorakouské zemské muzeum v Linci od jeho dcery.

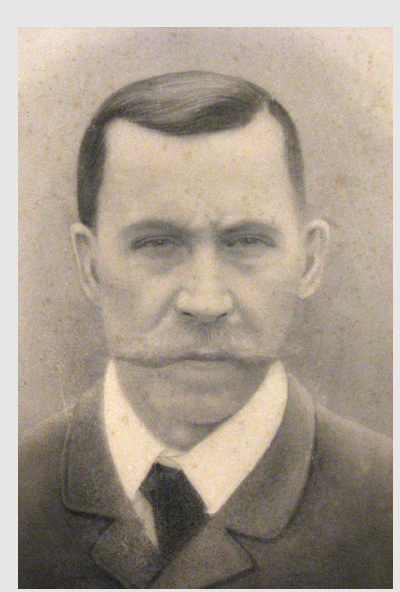

Obr. 2. Adolf Binder. Fotograf neznámý, zdroj www.zobodat.at. 
faunistické části a také vypustil nálezová data k druhům, které považoval za široce rozšířené. Obrovským přínosem Prodromu je kromě zveřejnění nových druhů motýlů pro Čechy především kritická revize starších publikovaných nálezů, jejímž výsledkem bylo vypuštění více než 200 druhů motýlů do té doby uváděných z Čech. Prodromus vyšel v lednu 1929.

\section{Zapomenutý Sterneckův Prodromus}

Bylo již uvedeno, že existuje starší verze Prodromu z roku 1919, kterou J. Sterneck, jak píše v úvodu pozdější vydané verze, vyhotovil celkem ve čtyřech strojových kopií, přičemž jednu poskytl O. Nickerlovi, jednu poslal do Československé společnosti entomologické v Praze, jednu do vídeňského přírodovědného muzea a jednu kopii si nechal pro sebe ${ }^{2}$. Zároveň dodává, že faksimile věnovaná Dr. Nickerlovi je nyní v Českém národním muzeu v Praze ${ }^{3}$. Při mých dosavadních pokusech se mě žádnou z uvedených kopií nepodařilo dohledat, avšak s ohledem na to, že se jednalo „pouze“ o nepublikované rukopisy nelze vyloučit jejich deponaci mimo evidované výtisky v knihovnách. Nakonec právě skutečnost, že se během stěhování Entomologického oddělení Národního muzea v roce 2014 z kunratického zámku do nových prostor v Horních Počernicích jedna kopie čirou náhodou našla, tuto možnost i v jiných institucích nevylučuje. Pozoruhodné je, že rukopis nebyl objeven mezi literárním fondem Entomologického oddělení, ale v neuspořádaném a desítky let nekontrolovaném skladišti archiválií určených k pozdější likvidaci. Tento objev je však o to více překvapující, že se evidentně nejedná o kopii darovanou 0 . Nickerlovi, jehož sbírky a pozůstalost jsou nyní majetkem Národního muzea, nýbrž o verzi, kterou si ponechal sám autor a do které po dobu následujících 10 let, tedy do vydání Prodromu v roce 1929, zapisoval nové údaje o výskytu motýlů, př́ipadně vlepoval celé pasáže nového, ručně psaného, textu. Věrím, že časem bude v archívech objevena i kopie, kterou J. Sterneck věnoval 0 . Nickerlovi, těžko však asi najdeme smysluplné vysvětlení, jakou cestou se ocitla autorova kopie v Národním muzeu. Je totiž nutné dodat, že rozsáhlá sbírka motýlů J. Sternecka je uložena v Př́rodovědném muzeu ve Vídni a bylo by tedy logické předpokládat, že právě zde bude deponována i její doprovodná evidence, sběratelova knihovna a jeho entomologické vybavení.

Nalezený rukopis má 986 stran strojopisného textu formátu A4, které jsou při hřbetní straně vždy po dvou listech vzájemně spojené úzkým papírovým proužkem a takto vzniklé dvoustrany jsou sestaveny do bloků, které byly následně svázány a opatřeny pevnými deskami. V celém rukopisu se prakticky nenachází žádná strana, do které by autor ručně nezapsal nějakou poznámku nebo doplňující informaci. K tomuto účelu používal černou nebo červenou tuš, písmo je drobné a úhledné. Delší poznámky jsou napsány na samostatném papíru a vlepeny do místa, ke kterému se doplněk váže. Stejně tak jako v tištěné verzi z roku 1929 jsou i v tomto rukopisu jednotlivé druhy chronologicky očíslovány. V obou verzích je posledním druhem hrotnokřridlec lesní (Phymatopus hecta), v rukopisu z roku 1919 má pořadové číslo 995 zatímco ve verzi publikované o deset let později 1028, což svědčí o nárůstu druhů. Rozdíl je i v tom, že starší verze zahrnuje přehled všech známých lokalit ke všem zařazeným druhům, zatímco ta pozdější u běžnějších druhů pouze číselné odkazy na zdroj. Rozdíl je pochopitelně i v rozsahu zdrojového fondu. Rukopis zahrnuje citace publikací do roku 1918 (částečně i z roku 2018), které končí pořadovým číslem 374. Ručními zápisky vlepenými na samostatných (nečíslovaných) listech jsou doplněny citace dalších publikací až do roku 1928. V tištěné verzi byly navíc některé citace doplněny až po jejich očíslování, a tak dalších 114 citací je uvedeno až na konci knihy. Podobně tomu je i s přehledem sbírkových zdrojů. Manuskript pracuje s 66 očíslovanými zdroji, tištěna verze s 82 (z toho 9 jich bylo do Prodromu doplněno až těsně před dokončením knihy na její konec a číslování všech sbírek bylo vypuštěno). Rukopis je fyzicky značně opotřebovaný, což svědčí o jeho mimo-

2 V rukopisu Sterneck (1919) píše, že rukopis existuje v pěti kopiích.

3 Dnes Národní muzeum. 
řádně intenzivním používání. Celkově lze konstatovat, že byt’ publikovaná verze je bohatší na druhy a časově pokrývá delší období, nepublikovaný rukopis obsahuje cenná faunistická data i k tehdy běžným druhům, které však dnes z velké části patří k ohroženým a jakýkoli faunistický údaj k nim je cenný.

\section{Jacob Sterneck versus Adolf Binder}

V úvodu tištěné verze Prodromu Sterneck zmiňuje, že základem díla je přibližně 60 tisíc nálezových dat od mnoha různých sběratelů. Významu tak rozsáhlé spolupráce si byl J. Sterneck dobře vědom, přesto pomoc dvou spolupracovníků byla minimálně v počátcích přípravy Prodromu pro Sternecka klíčová. Jedním z nich byl Viktor Richter, drážní úředník v Chomutově, který velkou měrou přispěl excerpcí dat ze staré literatury a druhým byl Adolf Binder, v té době lékař ve Stráži nad Ohří. Právě A. Binder byl na počátku 20. století jedním z nejpilnějších sběratelů motýlů v Čechách, navíc odborně vysoce erudovaný a zároveň s velkou ambicí faunu motýlů Čech publikačně zhodnocovat. A. Binder si ke své obrovské sbírce motýlů vedl rozsáhlé deníky s přesnými daty, které umožňovaly snazší excerpci nálezových dat pro další využití. V odstavci věnovaném A. Binderovi Sterneck (1919) píše o neúnavném badateli motýlí fauny Čech, jehož rozsáhlé informace z několik tisíc lokalit významně přispěly k doplnění Prodromu. Zároveň také zmiňuje, že A. Binder původně plánoval výsledky svých úlovků publikovat sám, avšak tohoto cíle se vzdal a nálezová data ze svých deníků poskytl pro účely Prodromu. Tento přístup J. Sterneck ocenil v rukopisu (1919) mimo jiné i tím, že svoje autorství Prodromu uvedl následujícím způsobem: „Za účasti četných badatelů a sběratelů českých motýlů, jakož i za zvláštní účasti Mudr. Adolfa Bindera (Warta) sestavil Dr. Jakob von Sterneck". Jak již ale víme, Prodromus ve skutečnosti vyšel až o deset let později, což vztahy obou entomologů navždy poznamenalo. Byt' se J. Sterneck v roce 1919 a počátkem 20. let snažil pro svůj Prodromus najít vydavatele, jak nejlépe mohl, neuspěl. V té době, a zejména po roce 1921, kdy A. Binder přesídlil do Rakouska a v Čechách již nesbíral, to bylo pro A. Bindera velké zklamání, a jak píše v úvodu své vlastní publikace (Binder 1994), v roce 1922 se rozhodl své deníkové záznamy shrnout, „aby zcela neupadly v zapomnění" a začal jednat s vydavateli měsíčníku pro pokročilé vědecké vzdělávání (Monatschrift für naturwissenschaftliche Fortbildung) sídlící v Teplé (Weihrauch in Tepl), kteří projevili zájem Binderovo dílo vydat jako zvláštní př́lohu. V roce 1925 vyšla první část (Binder 1925), avšak autor nebyl spokojen s prací vydavatele, a tak podstatně větší část Binderova rukopisu zůstala nevytištěna. Poté se A. Binder snažil přimět J. Sternecka, aby jeho rukopis zohlednil v Prodromu, k jehož vydání se již schylovalo. Ten to však odmítl a v dopise z ledna 1929 (tedy již po vydání Prodromu) Binderovi sděluje „že se domnívá, že mu již není nutné zasílat jeho návrh rukopisu, protože již od roku 1919 vlastní všechny jeho lokalizační záznamy, a navíc z publikace (Binder 1925) vidí, že mu neunikla žádná poznámka“ [cf. Binder 1994]. V lednu 1929 Prodromus konečně vychází (Sterneck 1929), avšak na titulní straně už chybí poukázání na výjimečné přispění A. Bindera a odstavec věnovaný A. Binderovi je výrazně zeštíhlen a omezuje se pouze na strohé konstatování „Rozsáhlá, bohatá sbírka, která zahrnuje sbírkové výsledky majitele téměr ze všech koutů Čech. Dobře označené, velmi spolehlivé. Všechny [sbírkové] doklady jsem viděl“. Zajímavý je též komentář k publikaci Bindera (1925) vedené pod pořadovým číslem 429, kde Sterneck (1929: 22) mimo jiné uvádí, že jednotlivé lokality byly do Prodromu zařazeny již před zveřejněním této práce na základě informací poskytnutých Binderem [tedy před r. 1919], takže každý odkaz na toto cenné dílo může být vynechán. Zároveň konstatuje, že ignoroval některé systematicky nevýznamné aberace, které Binder považoval za nutné uvádět. I z tohoto textu a taktéž z jeho zpo̊sobu napsání je už v této době cítit značný nesoulad a napětí ve vztazích obou pánů. V květnu 1929 píše A. Binder průvodní dopis ke své, dosud nepublikované práci, ve kterém vysvětluje svoje pohnutky ji vydat, mimo jiné poukazuje na nedostatky ve Sterneckově Prodromu, kterým šlo předejít, kdyby J. Sterneck akceptoval jeho nabídky. Zároveň v něm zdůrazňuje, že se nemá jednat o konkurenční dílo Prodromu. 
V Předmluvě vlastního manuskriptu poukazuje Binder (cf. Binder 1994) na fakt, že původně měly být deníkové záznamy použity jako stavební kameny do Prodromu motýlí fauny Čech, jakožto společného díla s J. Sterneckem a K. V. Richterem. Bohužel však, A. Binderovi se jeho dílo nepodařilo opublikovat a rukopis (spolu s průvodním dopisem) tak zůstal desítky let prakticky zapomenut (podrobněji viz box 3 ).
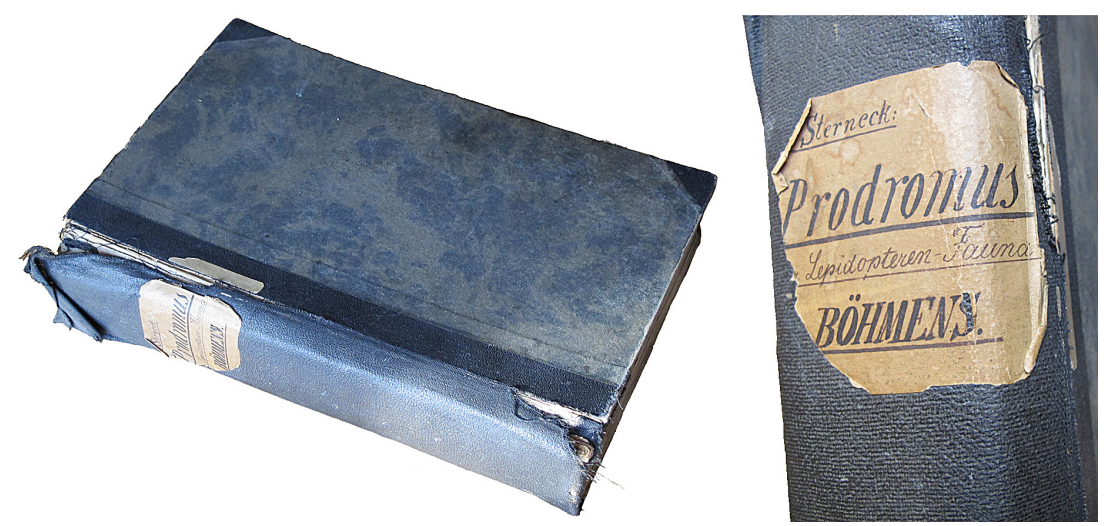

Obr. 3. Celkový pohled na svázaný rukopis „Prodromu“ (1919), ve výřezu vpravo detail popisky na hřbetu díla.

\section{Box 3: Binderovo dílo Př́spěvek k motýlí fauně Čech. Souhrn motýlů nalezených v Čechách v letech 1890 až 1920}

V roce 1994 vydal Dr. Ulf Eitschberger z Marktleuthenu zapomenutý rukopis Adolfa Bindera, který vznikl ve 20. letech 20. století a který pojednává o motýlech Čech. V roli editora v předmluvě $k$ tomuto dílu popisuje, jak se $k$ němu rukopis dostal a jaké pohnutky ho $k$ jeho vydání vedly. $U$. Eitschberger získal nezávisle na sobě dvě strojopisné kopie Binderova rukopisu, které se lišily podobou, ale měly stejný obsah. První rukopis pocházel z antikvariátu Goecke \& Evers, který jej získal z pozůstalosti významného entomologa Burcharda Albertiho (1898-1988), druhý pak získal v rámci zakoupení knihovny zesnulého Vladimíra Bronislava Poláčka (1926-1990)‥ Zde je možné doplnit, že v Národním muzeu je uložena třetí kopie Binderova rukopisu². Publikováním tohoto rukopisu byl naplněn odkaz Binderova díla a pro českou faunistiku představuje významný doplněk poznání motýlí fauny tehdejši doby. Již letmým porovnáním Binderovy práce a Sterneckova Prodromu je zřejmé, že Binderova práce byla připravena v metodickém souladu s Prodromem (např stejné řazení druhủ, shodné názvosloví apod.), čímž se potvrzuje původní záměr deklarovaný autorem. Verze vydaná v roce 1994 U. Eitschbergerem zahrnuje nejen dosud nepublikované informace, ale souhrnně prezentuje veškeré údaje včetně těch, které Binder zveřejnil samostatně v letech 1910 a 1925 (Binder 1910, 1925), a to včetně lokalit u běžných druhủ. Tyto publikované nálezy Sterneck (1929) do Prodromu s odkazem na zdroj zahrnul všechny (byt' u běžných druhů nejsou uvedeny lokality, pouze zdroj) a stejně tak i velkou část ostatních Binderových nálezů pod zkratkou jeho jména „B“. Bohužel mnohé nálezy doplněné Binderem do svého soupisu až po roce 1919, tedy po dokončení první verze Prodromu, již v publikované verzi chybí. Dnes je obtížné se dopátrat, zda Binder nabídl svůj soupis Sterneckovi pozdě, tedy v době, kdy už byla nová verze Prodromu nachystána pro tisk (nebo dokonce vytištěna), anebo zda se Sternecka př́liš dotkl fakt, že se v polovině 20. let Binder rozhodl publikovat svoje nálezy sám, a proto se již nechtěl Binderovou prací dále zabývat. V každém prípadě Binderovo dílo, byt' publikované až 75 let po vydání Prodromu, představuje významný zdroj o historickém výskytu velkých motýlů u nás.

1 Poláčkova knihovna byla nesmírně rozsáhlá. Knižní část, kterou zakoupil U. Eitschberger, obsahovala více než 2,5 tuny knih uložených ve více než 120 banánových krabicích, knihovna separátů byla uložena ve 40-50 krabicích stejného typu a je uložena v Národním muzeu v Praze (tzv. Poláčkův fond).

2 Rukopis „Binder A. 1929: Beitrag zur Schmetterlingsfauna Böhmens. Eine Zussammefassung der Schmetterlingsfunde in Böhmen im Zeitraume 1890 bis 1920 je uložen v knihovně Entomologického oddělení Národního muzea pod číslem 431 D 3. 


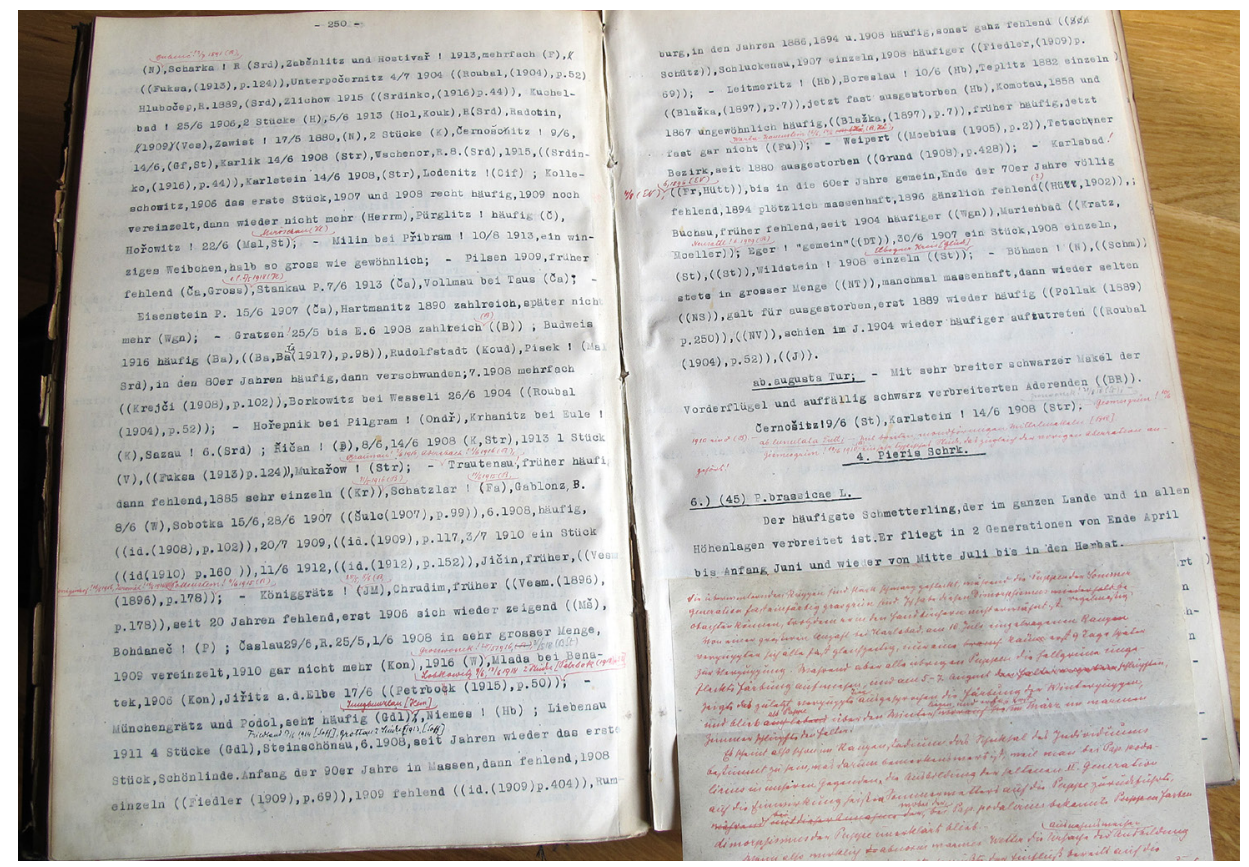

Obr. 4. Dvoustrana 250-251 rukopisu věnovaná bělásku ovocnému (Aporia crataegi). V tištěné verzi z roku 1929 je rozsáhlý přehled lokalit nahrazen pouze číselnými odkazy na zdroj.

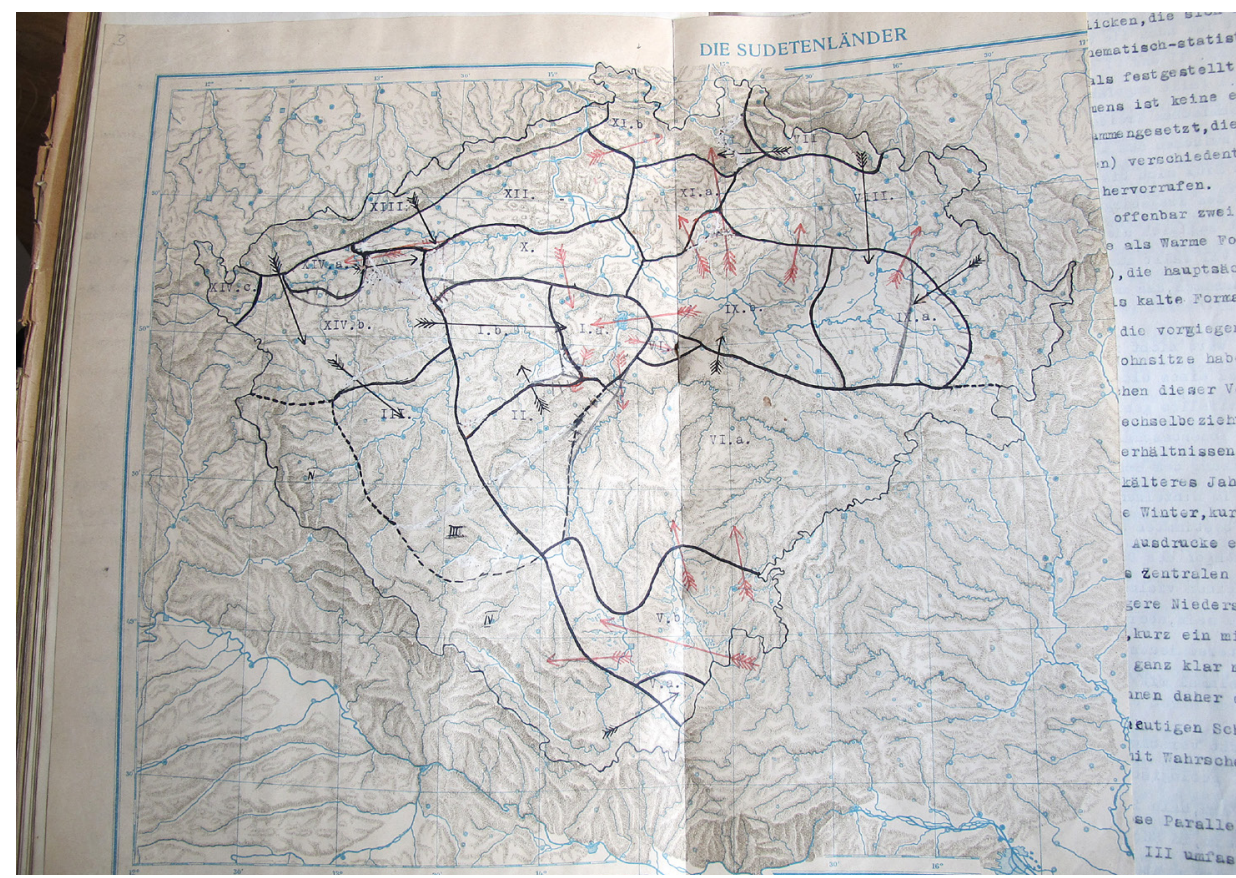

Obr. 5. Součástí rukopisu je také mapka, která doplňuje rozsáhlou kapitolu věnovanou regionům Čech. Červené šipky značí ovlivňování chladnějších regionů motýlími druhy z klimaticky teplejších oblastí, černé šipky signalizují opačný směr migrace. 


\section{Zpět k zapomenutému Prodromu...}

Vydání Binderova díla po tak dlouhé době byl jistě záslužný čin, a to nejen z pohledu faunistiky motýlů Čech, ale i z hlediska kulturně historického. Je třeba, pokud je to v našich silách, oživovat př́nos našich předků pro entomologii a připomínat si jejich zásluhy o vědecký pokrok. Pro Jacoba Sternecka jistě nebylo snadné svoje dílo z roku 1919 ochudit o tolik užitečných informací, aby mohlo být nakonec, byt' s velkým zpožděním, vůbec vydáno. Myslím, že podobně jako u Binderova „Příspěvku“ se i v případě nevydaného Sterneckova rukopisu nabízí podobné řešení, které by nám a dalším generacím lepidopterologů umožnilo využívat Sterneckovo dílo v plném rozsahu. S ohledem na rozsah rukopisu se v první fázi vybízí možnost rukopis naskenovat a zveřejnit na internetu $v$ autentické podobě. $V$ budoucnu by ale jistě bylo žádoucí rukopis přepsat a vydat například formou on-line monografie. Věřím, že se to jednou podaří.

\section{Poděkování}

Tento příspěvek by nemohl vzniknout, kdyby se Sterneckův rukopis nepodařilo najít. Zásadní zásluhu na objevu má tehdejší kolega Vítězslav Kubáň, který v říjnu 2014 prováděl v rámci stěhování Entomologického oddělení jednu z posledních kontrol historických prostor zámku v Kunraticích před jeho definitivním opuštěním, a to i těch nejzazších koutů. A právě v jednom z nich k tomuto objevu došlo. Za záchranu a předání rukopisu mu proto patří upřímné poděkování. Lukáši Sekerkovi děkuji za doplňující informace k Poláčkovu fondu a Kristině Lexové za pomoc při překladech staroněmeckých textů a vylepšení angličtiny. Janu Liškovi děkuji za poskytnutí obrázků 6 a 7. Práce vznikla za finanční podpory Ministerstva kultury ČR v rámci institucionálního financování dlouhodobého koncepčního rozvoje výzkumné organizace Národní Muzeum (DKRVO 2019-2023/5.I.c, 00023272).

\section{Literatura}

Anonymus, 1935: Dr. med. Adolf Binder. - Zeitschrift des Österreichischen Entomologischen Vereins 20, 3: 17

Binder A., 1910: Macrolepidopteren von Gratzen (Südböhmen). - Internationale entomologische Zeitschrift 4: 136-138, 141-142, 148-149, 154, 160-161.

Binder A., 1925: Beitrag zur Schmetterlingsfauna Böhmens. - Sonderbeilage zur Monatschrift für naturwissenschaftliche Fortbildung 19, Sonderbeilage zu Heft 4/5-11 /12, 28 pp.

Binder A., 1994: Beitrag zur Schmetterlingsfauna Böhmens. Eine Zusammenfassung der Schmetterlingsfunde in Böhmen im Zeiträume 1890 bis 1920. - Neue Entomologische Nachrichten 32: 1-150.

Laštůvka Z. \& Liška J., 2011: Komentovaný seznam motýlů České republiky. Annotated checklist of moths and butterflies of the Czech Republic (Insecta: Lepidoptera). - Brno: Biocont Laboratory, $148 \mathrm{pp}$.

Müller L., 1935: Dr. Adolf Binder. - Zeitschrift des Österreichischen Entomologischen Vereins 20, 4: 30-32.

Nickerl O., 1907: Beiträge zur Insekten-Fauna Böhmens. V. Die Spanner des Königreiches Böhmens (Geometridae) als Fortsetzung zu Prof. Dr. Franz A. Nickerl's Synopsis der Lepidopterenfauna Böhmens. - Verlag der Gesellschaft für Physiokratie in Böhmen, Prag, $71 \mathrm{pp}$.

Sterneck J., 1919: Prodromus der Schmetterlingsfauna Böhmens. I. Teil: Macrolepidotera. Nepublikovaný manuskript, depon. - Praha: Národní muzeum, 986 pp.

Sterneck J., 1929: Prodromus der Schmetterlingsfauna Böhmens. - Karlsbad: Jacob Sterneck, 297 pp.

Sterneck J. \& Zimmermann F., 1933: Prodromus der Schmetterlingsfauna Böhmens II. (Microlepidoptera). - Karlsbad: Jacob Sterneck, 168 pp. 


\section{Summary}

\section{The famous Prodromus of Bohemian butterflies and moths in context}

Jan Šumpich

In 2014, a manuscript by Jacob Sterneck titled Prodromus der Schmetterlingsfauna Böhmens was uncovered during relocation of the entomological department from Kunratice Castle to the National Museum's new storage facilities in Horní Počernice (both locations within Prague). Interestingly, the manuscript is dated to 1919, despite the final book not being published until 1929. In the introduction to his book, Sterneck (1929) attributes this failure to publish at the time to a lack of funds, noting also that a total of four copies of the manuscript were made. The copy found in 2014 belonged to J. Sterneck himself, who used it to record all new information gained between 1919-1928. Compared to the final publication, the manuscript is considerably longer despite covering a shorter time period, and contains introductory chapters as well as data on more common species that were evidently later removed. We know that Sterneck (1919) collaborated intensively with Adolf Binder on the preparation of the manuscript, a relationship which seems to have degraded due to the aforementioned publishing issues, as well as A. Binder's subsequent efforts to have his work released independently. Binder ultimately only succeeded in having a small portion of his work published at the time, a fact remedied long after his death by Ulf Eitschberger (Binder 1994). Sterneck's manuscript from 1919 is particularly valuable due to its inclusion of a large number of faunistic records missing from the published version.

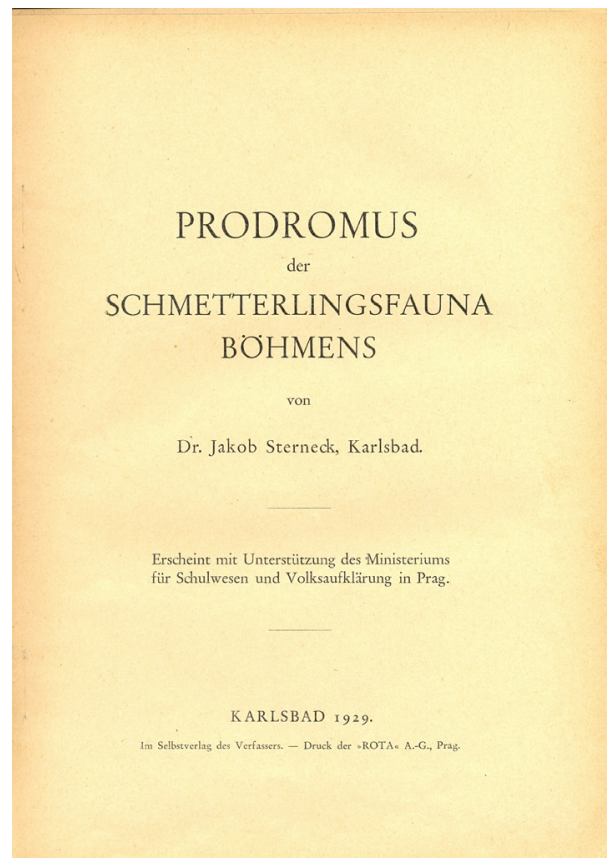

Obr. 6. Titulní strana publikovaného Prodromu (Sterneck 1929).

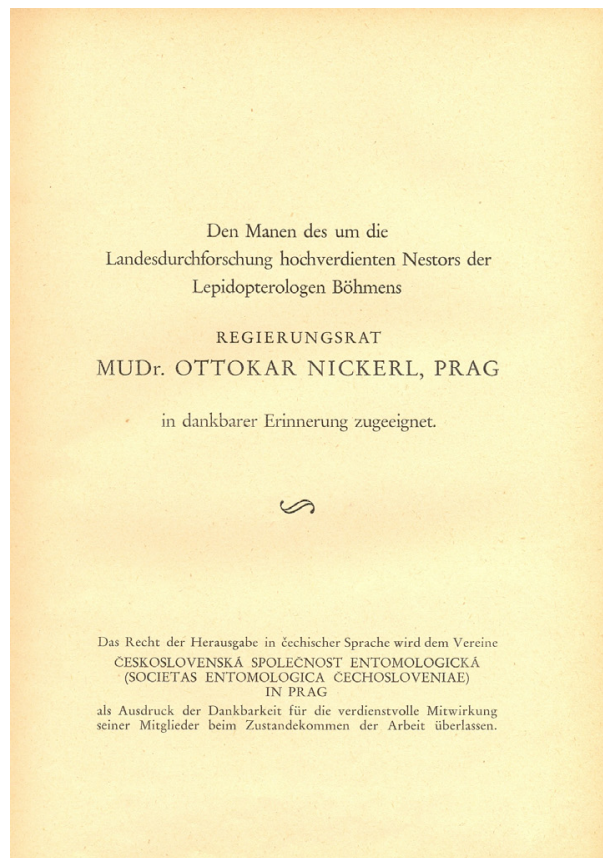

Obr. 7. J. Sterneck dedikoval svůj Prodromus O. Nickerlovi, nestoru lepidopterologie v Čechách. 